Monográfico: Reflujo Vesicoureteral

Arch. Esp. Urol., 61, 2 (218-228), 2008

\title{
VESICO URETERAL REFLUX AND ELIMINATION DISORDERS
}

\author{
I. Alova and H. B. Lottmann.
}

Hôpital des Enfants Malades. Paris. France.

\begin{abstract}
Summary.- Two kinds of elimination disorders can be associated with Vesico Ureteral Reflux (VUR): pure bladder elimination disorders or combination of bladder and bowel elimination disorders. An elimination disorder is always a factor which worsens the prognosis of VUR, as it increases the risk of infectious complications and thus presents a threat for the upper urinary tract. Regarding pure bladder elimination disorders, a chronic urine residue is observed in four clinical situations: the syndrome megacystis-mega ureter; the mega bladder without mega ureter, but with VUR; high grade massive VUR without a mega bladder; organic obstructions of the urethra lsuch as posterior urethral valves.). VUR associated with urine and fecal elimination disorders cover functional pelvi perineal dyscoordination, bladder sphincter dysynergia, disturbances of visceral motricity and anal sphincter function. The most characteristic type is represented by the neuropathic detrusor-sphincter dysfunction; also enter in this category neurogenic non-neurogenic
\end{abstract}

bladders (Hinman's syndrome); However the vast majority of urine and fecal elimination disorders is represented by non neuropathic perineal dyscoordination associating at various degrees: voiding postponement, lack of sphincter relaxation during micturation, interrupted voiding, and constipation.

The diagnosis of elimination disorders associated with VUR is based on non invasive investigations such as anamnesis and drinking/voiding chart in children and adolescents, and "four observation test" in infants. Ultrasound and uroflowmetry are also useful tools. Invasive investigations include mainly voiding cystourethrography and urodynamics, ideally combined in video urodynamic studies. The management of urinary and intestinal elimination disorders is based on the prevention of infections, the suppression of the post voiding residual urine and the treatment of an associated constipation. If surgical treatment of VUR is needed, it must be associated to the management of elimination disorders in the peri operative period. In many instances, an appropriate treatment of elimination disorders often leads to the VUR resolution.

Keywords: Vesicoureteral reflux. Dysfunctional voiding. Bladder sphincter dyssynergia. Neuropathic bladder. Eimination disorders. Hinman syndrome. Ochoa syndrome. Clean intermittent catheterization.

Resumen.- Dos tipos de trastornos de la excreción pueden asociarse con el reflujo vesicoureteral (RVU): trastornos puros del vaciado vesical o combinaciones del vaciado vesical y la excreción de heces. Un trastorno de la excreción es siempre un factor que empeora el pronóstico del RVU, porque aumenta el riesgo de complicaciones infecciosas y por lo tanto representa una amenaza para el tracto urinario superior. En relación con los trastornos puros del vaciado vesical, se observa un residuo urinario crónico en cuatro situaciones clínicas: el síndrome megavejiga-megauréter, la megavejiga sin megauréter pero con RVU, el RVU de alto grado masivo sin megavejiga, y obstrucciones orgánicas de la uretra (como valvas de uretra posterior). 
El RVU asociado con trastornos de la excreción urinaria y fecal cubre la descoordinación pelviperineal, la disinergia detrusoesfinteriana, y las alteraciones de la motricidad visceral y de la función del esfínter anal. El tipo más característico está representado por la disfunción detruso-esfinteriana neuropática; también entran en esta categoría las vejigas neurógenas no neurogénicas (síndrome de Hinman); sin embargo la inmensa mayoría de los trastornos de la excreción urinaria y fecal están representadas en la descoordinación perineal no neuropática que se asocia en varios grados: retraso de la micción, falta de relajación del esfínter durante la micción, micción interrumpida y estreñimiento.

El diagnóstico de los trastornos de la excreción asociados con RVU se basa en pruebas no invasivas como la anamnesis, los diarios de ingesta líquida y miccionales en niños y adolescentes, y cuatro pruebas de observación en lactantes. La ecografía y la flujometría son también pruebas útiles. Las pruebas invasivas incluyen principalmente la cistouretrogrrafía miccional seriada y el estudio dinámico, idealmente combinadas en los estudios videourodinámicos. El tratamiento de los trastornos de la excreción urinaria e intestinal se basa en la prevención de las infecciones, la supresión del residuo postmiccional y el tratamiento del estreñimiento asociado. Si fuera necesario tratamiento quirúrgico del RVU, debe asociarse con el tratamiento perioperatorio de los trastornos de la excreción. En muchos casos, un tratamiento apropiado de los trastornos de la excreción conduce con frecuencia a la resolución del reflujo vesicoureteral.

Palabras clave: Reflujo vesicoureteral. Micción disfuncional. Disinergia detrusoesfinteriana. Vejiga neurógena. Trastornos de la excreción. Síndrome de Hinman. Síndrome de Ochoa. Auto cateterismo.

\section{INTRODUCTION}

Two kinds of elimination disorders can be associated with Vesico ureteral reflux (VUR): pure bladder elimination disorders or combination of bladder and bowel elimination disorders. An elimination disorder is always a factor which worsens the prognosis of VUR, as it increases the risk of infectious complications and thus present a threat for the upper urinary tract. Elimination disorder once identified has to be managed adequately.

\section{Vesico ureteral reflux and isolated bladder elimi- nation disorders}

A chronic bladder urine residue is observed in four clinical situations: the syndrome megacystis-mega ureter; the mega bladder without mega ureter, but with VUR; high grade massive VUR without a mega bladder; organic obstructions of the urethra (such as posterior urethral valves ...).

\section{Syndrome mega cystis - mega ureter}

The megacystis-megaureter syndrome - has a radiological definition: it consists of an association of a huge bladder, usually with a thin wall and a high grade primitive VUR (Figure la). The massive ureteral dilatation is the consequence of the constant recycling of high volume of urine refluxing from the bladder into the ureters. Burbige et al reported a series of 29 children diagnosed between the newborn period up to the age of 13 years: $74 \%$ of them had presented febrile urinary tract infections. In fourteen initial cases the inaccurate diagnostis of urethral obstruction was

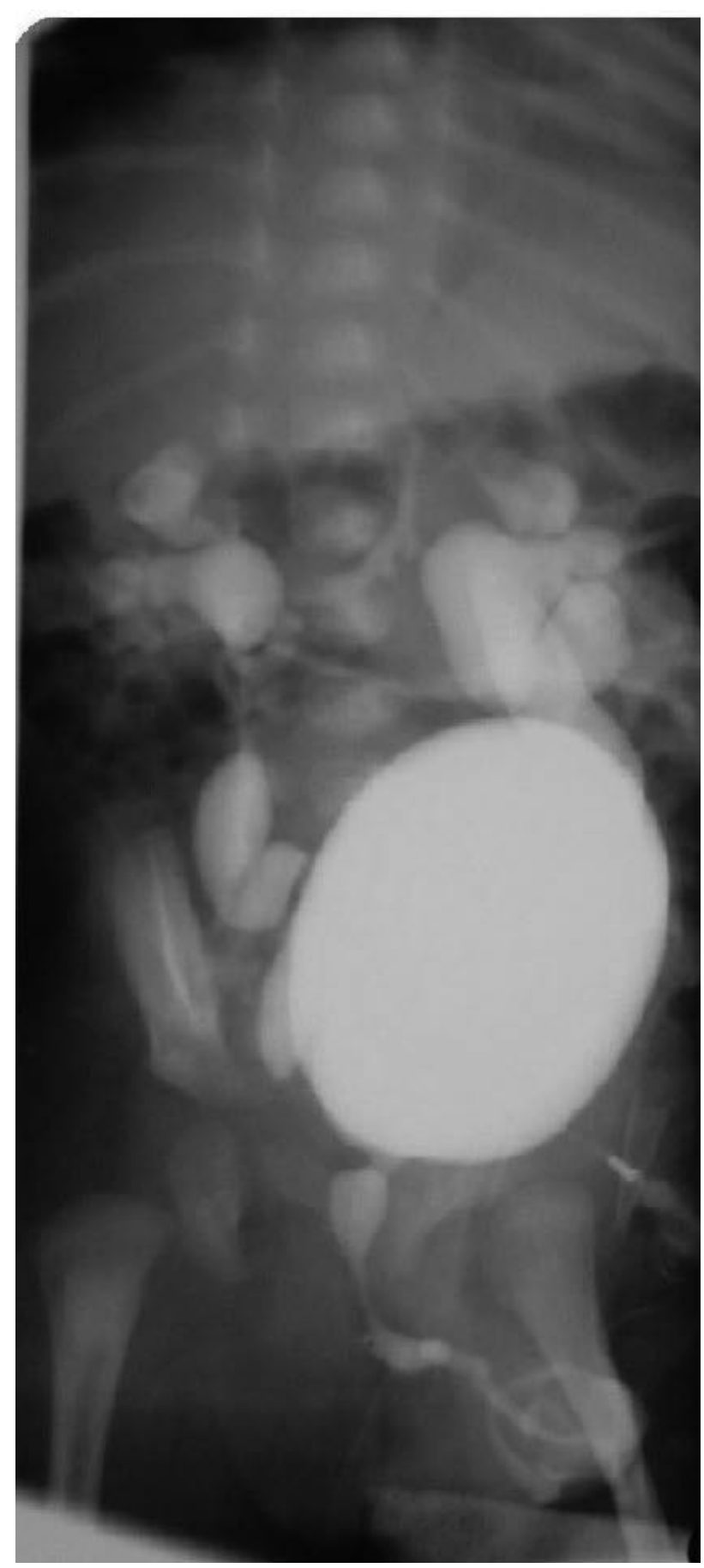

FIGURE 1A. Vesico ureteral reflux and isolated bladder elimination disorders:

a- Syndrome mega cystis - mega ureter. 
established, inappropriate conservative management and five of them deteriorated their renal parenchyma. In the 15 more recent cases an early stage vesico-ureteral reimplantation resulted in the preservation of the renal function and suppression of post voiding residue (1). The same group of authors underlines the interest of an antenatal diagnostis , an early preventive antibioprophylaxis even if most of these patients will need surgery due to recurrent infections and/or persistent massive VUR (2).

\section{Megacystis with VUR without mega ureter}

A large bladder with a thin wall can also be associated with a low grade VUR (Figure 1b). Contrary to the above described situation, the megacystis is not consecutive to a massive refluxing volume of urine, but more likely to a deficient contractility of the detrusor. VUR is due to a muscular back support deficit in the intra mural ureteral tract. These patients frequently have a significant amount of residual urine, and even if an antenatal diagnosis has been established, an early preventive antibioprophylaxis is

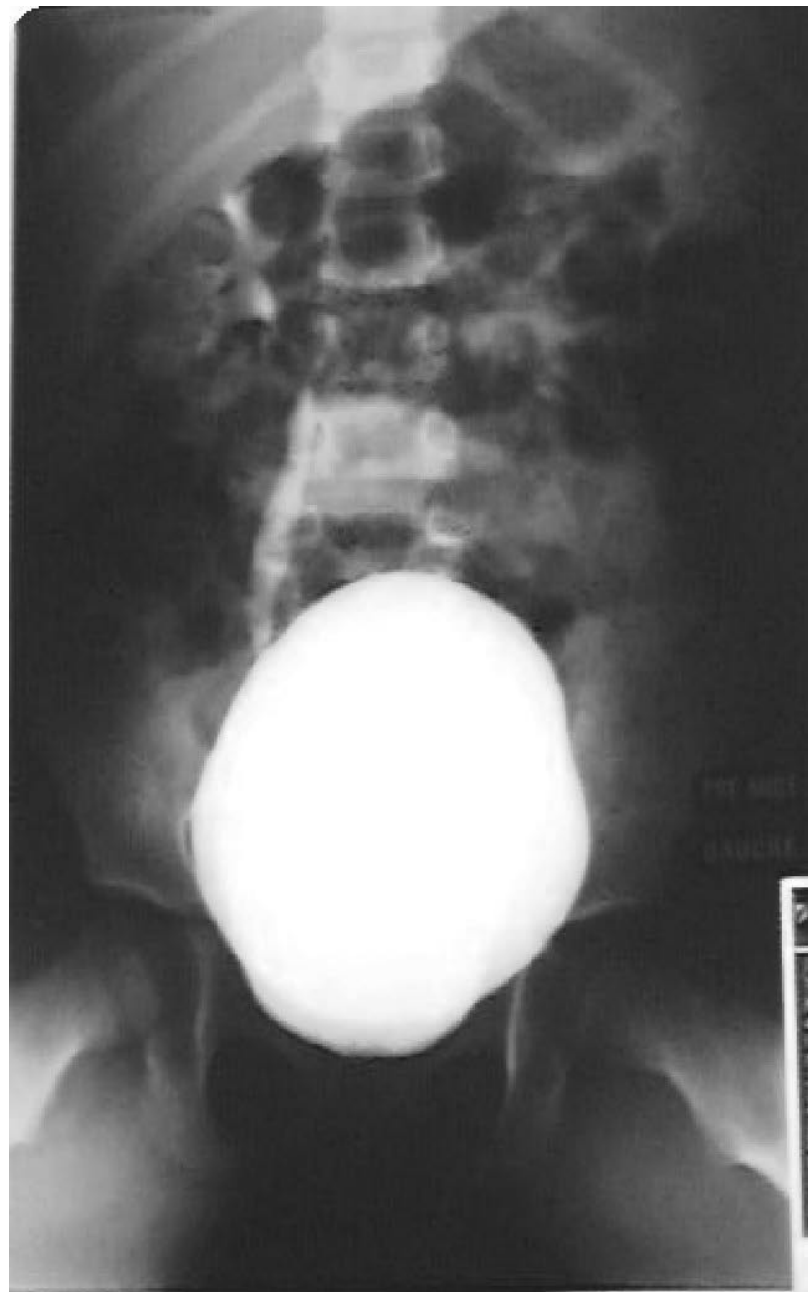

FIGURE 1B. Vesico ureteral reflux and isolated bladder elimination disorders:

b-Megacystis with VUR without mega ureter not effective to prevent recurrent severe pyelonephritis in the neonatal period. A vesico ureteral reimplantation usually gives unsatisfactory results and essentially the regular and complete evacuation of residual urine, if necessary via clean intermittent catheterisation, is the most appropriate therapeutic approach.

\section{Massive VUR without megacystis}

High grade massive VUR with a dilatation of upper urinary tract, mostly bilateral, associated with a small bladder capacity is almost exclusively observed in male infants (Figure 1c) (3-5). The largest series of patients, reported by Yeung and al includes 155 infants. $28 \%$ of boys in this study and only $5 \%$ of girls presented extended parenchymal lesions (4). A majority of these boys with a high grade vésico-ureteral reflux had bladder dysfunction with a very high voiding pressures, associated with a small functional capacity and overactivity during the filling phase (6). These infants had less number of voidings, compared to infants of the same age and significant amount of residual urine (7). In most cases these hyper contractile, small functional capacity bladders with high voiding pressures evolute to large capacity hypo-contractile low-pressure bladders with an incomplete emptying during voiding (8). This evolu-

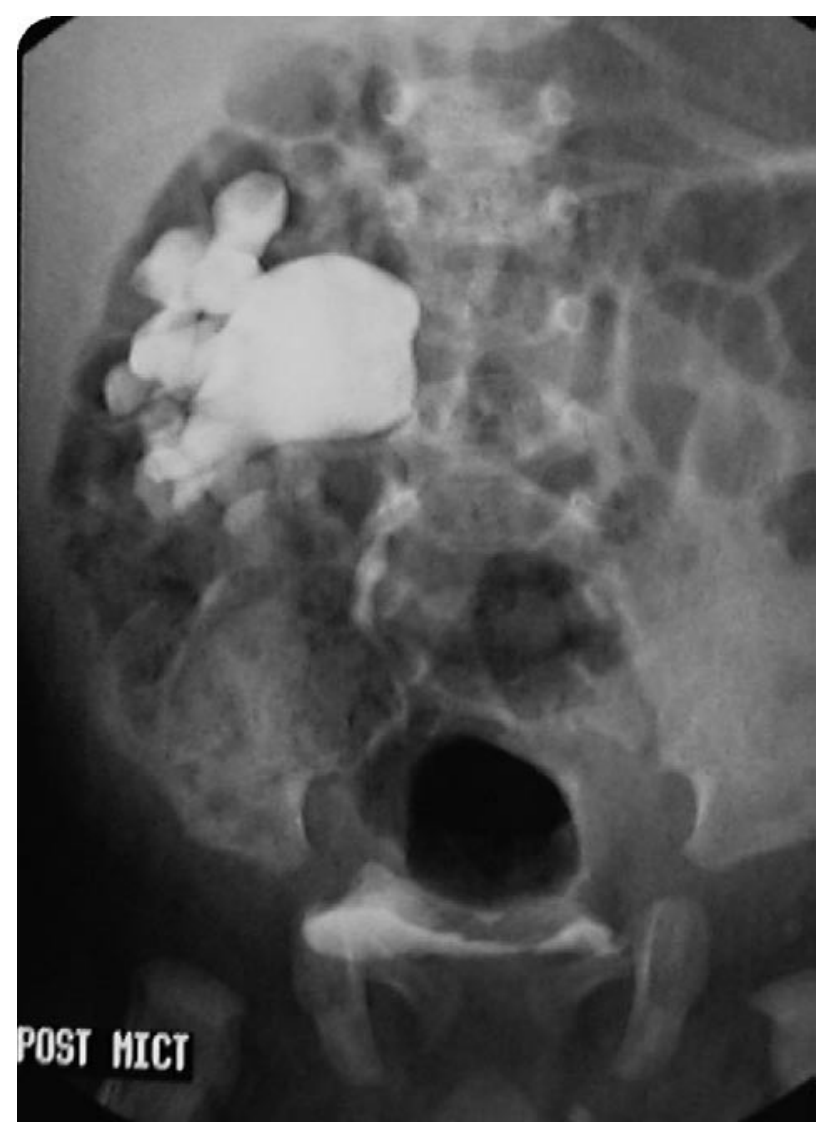

FIGURE 1C. Vesico ureteral reflux and isolated bladder elimination disorders:

c-Massive VUR without megacystis 
tion, is similar to that of bladders above a cervico-urethral organic obstruction (such as valve bladders), and could be due to high outlet resistances related to a congenital detrusor-sphincter dyscoordination.

\section{Structural cervico-urethral obstructions}

They are almost exclusively represented by posterior urethral valves (Figure 1d). One third of boys, who have a posterior urethral valve at birth, will present at some stage a more or less severe renal insufficiency (9-10). Even if renal dysplasia is the main factor of renal failure, urinary tract infections, vésico-ureteral reflux and especially associated bladder dysfunction have a negative impact on the remaining renal parenchyma (11). Bladder dysfunction is secondary to the cervico urethral obstruction and persists

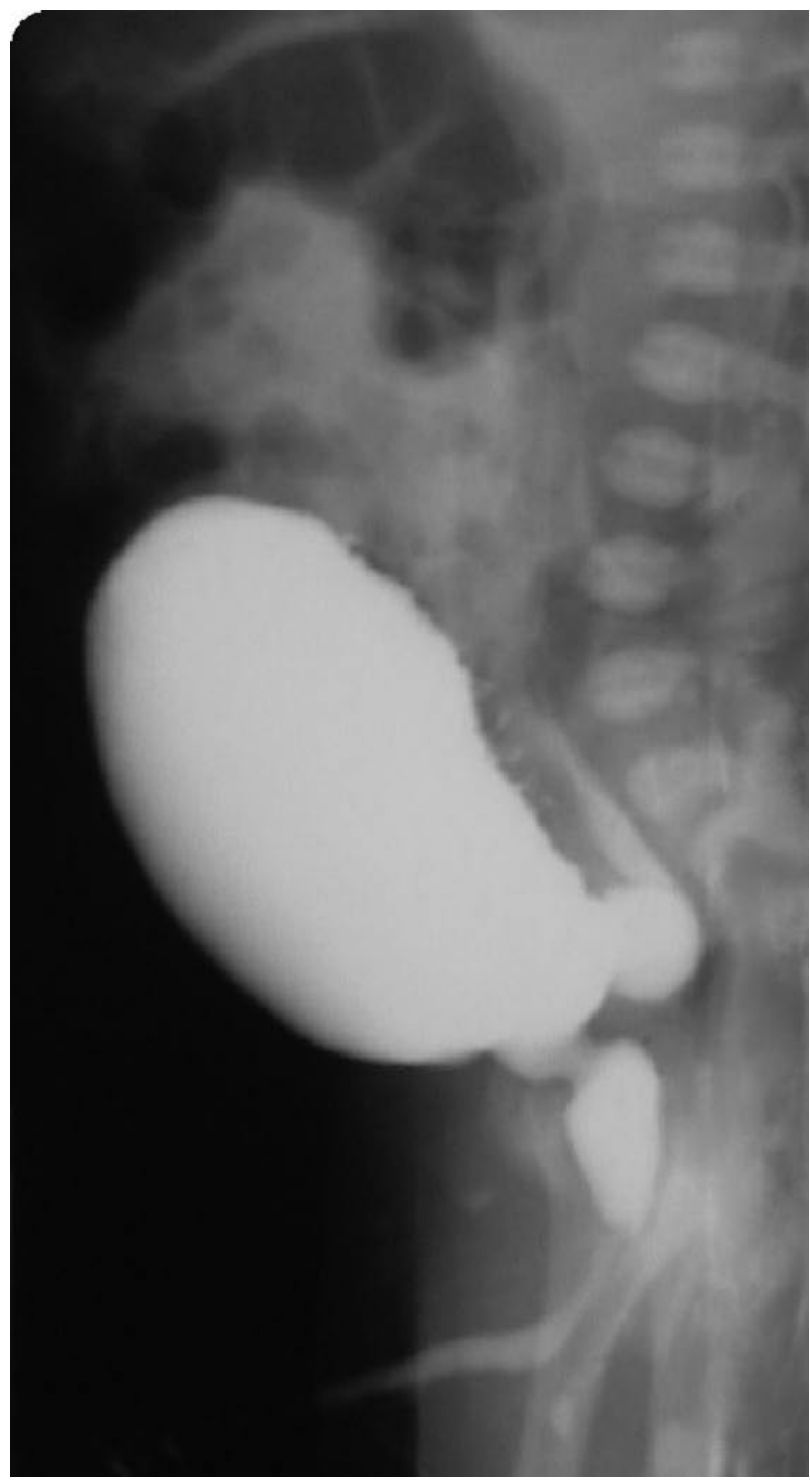

FIGURE 1D. Vesico ureteral reflux and isolated bladder elimination disorders:

d- Structural cervico-urethral obstructions: posterior urethral valve. during childhood and adolescence even after resection of the valve (12-13). Holmdahl et al demonstrated, that an initial small functional capacity hyper contractile bladder will end up as a hypo contractile bladders with a large functional capacity; default of emptying is constantly observed (14). An association of such a bladder dysfunction with residual urine and VUR is a pejorative factor for the renal parenchyma. An other example of situation with a high risk for the upper urinary tract is that of a bladder extrophy, after total reconstruction in the neonatal period. These children have very small bladders, almost constant bilateral vésicoureteral reflux because of elevated peripheral resistance, created by cervico-urethral reconstruction, associated with a disturbance of bladder contractility. Most of these patients present in the neonatal period frequent and severe episodes of pyelonephritis (Figure 1e).

\section{VUR and association of urine and fecal elimina- tion disorders}

These disorders cover functional pelvi perineal dyscoordination, bladder sphincter dysynergia, disturbances of visceral motricity and anal sphincter function. The

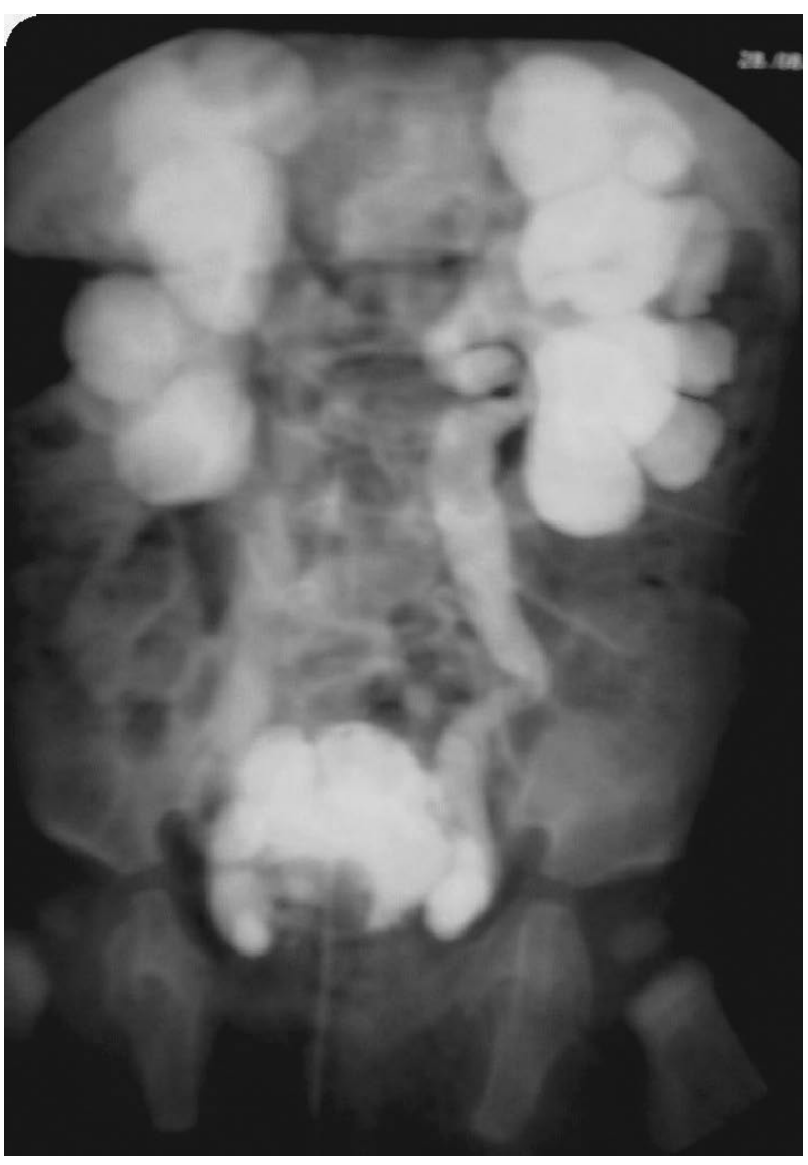

FIGURE 1E. Vesico ureteral reflux and isolated bladder elimination disorders:

e- Bladder exstrophy: reconstruction of bladder neck in the neonatal period, massiveVUR; recurrent pyelonephritis. 
most characteristic type is represented by the neuropathic detrusor-sphincter dysfunction; also enter in this category neurogenic non-neurogenic bladders (Hinman's syndrome); However the vast majority of urine and fecal elimination disorders is represented by non neuropathic perineal dyscoordination associating at various degrees: voiding postponement, lack of sphincter relaxation during micturation, interrupted voiding, and constipation.

\section{Elimination disorders, associated with a VUR related to neu- rogenic detrusor-sphincter dyssynergia}

VUR associated with a bladder-sphincter dysfunction is secondary to alteration of detrusor characteristics and detrusor-sphincter dyscoordination (Figure 2a). Low bladder compliance and elevated peripheral resistance lead both to VUR and incomplete bladder emptying. Simultaneous measurement of detrusor pressure and peripheral resistances allowed Mc Guire et al to define the bladder pressure at which occurs urine leakage (leak point pressure or (PP) and to correlate that pressure with a risk of progressing renal parenchymal lesions, particularly when a high pressure VUR is present. 42 children with meningomyelocele were followed during seven years. 15 (68\%) of 22, who had a leak point pressure above $40 \mathrm{~cm}$ of water, had a VUR (15). VUR and elevated bladder pressures represent a direct threat for to the renal parenchyma; this threat is amplified by urinary tract infections secondary to urinary stasis related to chronicle post voiding residue and fecal stasis due to default of colon contractility. Cohen et al in a retrospective study of 180 children with myelomeningocele, who were followed by cystographies and DMSA renal scans, observed that 90 children (50\%) developped renal scars along follow up; $75 \%$ among them had a documented VUR

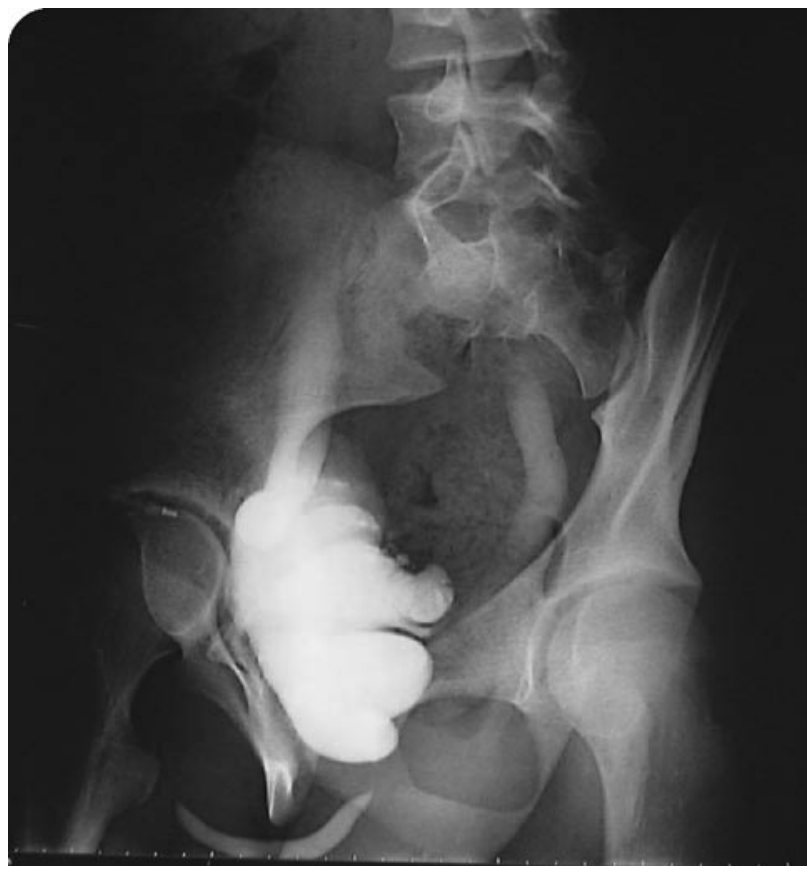

FIGURE 2A. Neuropathic bladder with high pressure VUR secondary to sacrum agenesia.
(16). An appropriate preventive management of bladder and intestinal emptying are often effective to prevent the development of VUR and it's parenchymal complications. We reviewed the charts of 150 patients with a neurogenic bladder, followed at a single institution: 68 of them with a congenital neuropathic bladder, who's appropriate management had been delayed, $22(32 \%)$ had a VUR and half of them -12-had renal scarring while amongst the 51 children with an acquired neuropathic bladder, and who generally have been managed at an early stage with Clean Intermittent Catheterization $(\mathrm{CIC})$ and anticholinergics, 8 $(16 \%)$ have developed a VUR and only 3 renal parenchyma lesions (17).

\section{Elimination disorders, associated with a VUR secondary to severe non neurogenic detrusor-sphincter dyssynegia}

This condition was first described by Frank Hinman in the early seventies (18). The detrusor-sphincter dissynergia (DSD)and its consequences are comparable with that of a DSD of neuropathic origin, but no neurological lesion can be identified (so the diagnosis is made by elimination of a neurological condition). In fact, an inability of the sphincter to relax or even worse it's active contraction during the voiding phase is of comportemental origin; it is often observed in case of severe psychological traumatism (parental separation, victims of sexual abuse, parental alcoholism etc). The clinical signs are: urinary incontinence, recurrent urinary tract infections, constipation and encopresis. VUR secondary to detrusor-sphincter dysfunction is often a high pressure dilating reflux in the context of a low bladder compliance Figure $2 \mathrm{~b}$. Such VUR is observed in more than half of the patients and presents a real danger for the renal parenchyma, as a majority of these patients have renal scars at the moment of the diagnosis. The renal prognosis is particularly pejorative as the management of these patients

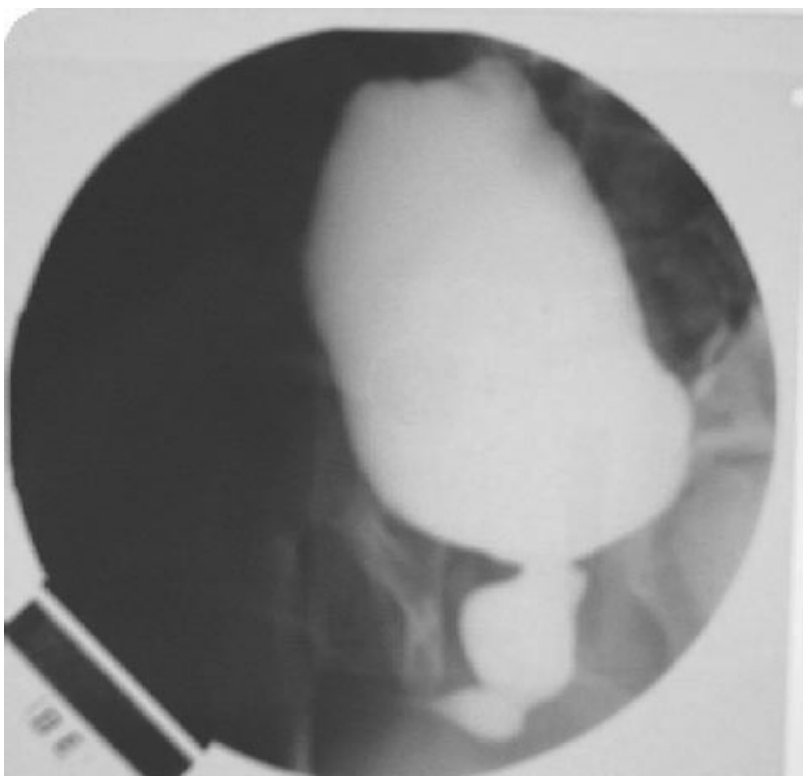

FIGURE 2B. Bladder sphincter dyssinergia in an Hinman syndrome. 
is particularly difficult and recurrences are frequent (19-21). A particular case of non neuropathic neuropathic bladder is the Ochoa syndrome probably related to a dysfunction of the pontine micturation center together with a dyscoordination of the facial muscles giving the patient a very particular crying expression while smiling 20 ; due to an often late diagnosis, most of these patients develop significant parenchymal damage and renal insufficiency. Figure $3 \mathrm{a}-\mathrm{c}$; although classified in this chapter, there is usually no fecal elimination disorder associated with the Ochoa syndrome

\section{Elimination disorders and VUR associated with a perineum- sphincter dyscoordination}

Whatever could be the initial reason (interrupted voiding, adaptation to the uninhibited bladder contraction due to overactive bladder etc), some children develop an habit to contract their urethral sphincter as a reaction to the contractions of their bladder. Sometimes they reinforce the tonus of the sphincter contracting the muscles of the perineum and adopting the characteristic postures (cross their legs, "dancing" at the place, squatting etc). These inappropriate habits during the filling phase of the bladder could create a deficit of relaxation of the sphincter during the voiding phase and as a consequence incomplete bladder emptying and secondary VUR. This dyscoordinated voiding generally is associated with an equivalent dysfunction of the anal sphincter with constipation (which can also induce uninhibited bladder contractions). Incomplete relaxation of the sphincter presents like a staccato voiding or plateau voiding at uroflowmetry. Reinforcement of outlet resistances during bladder filling

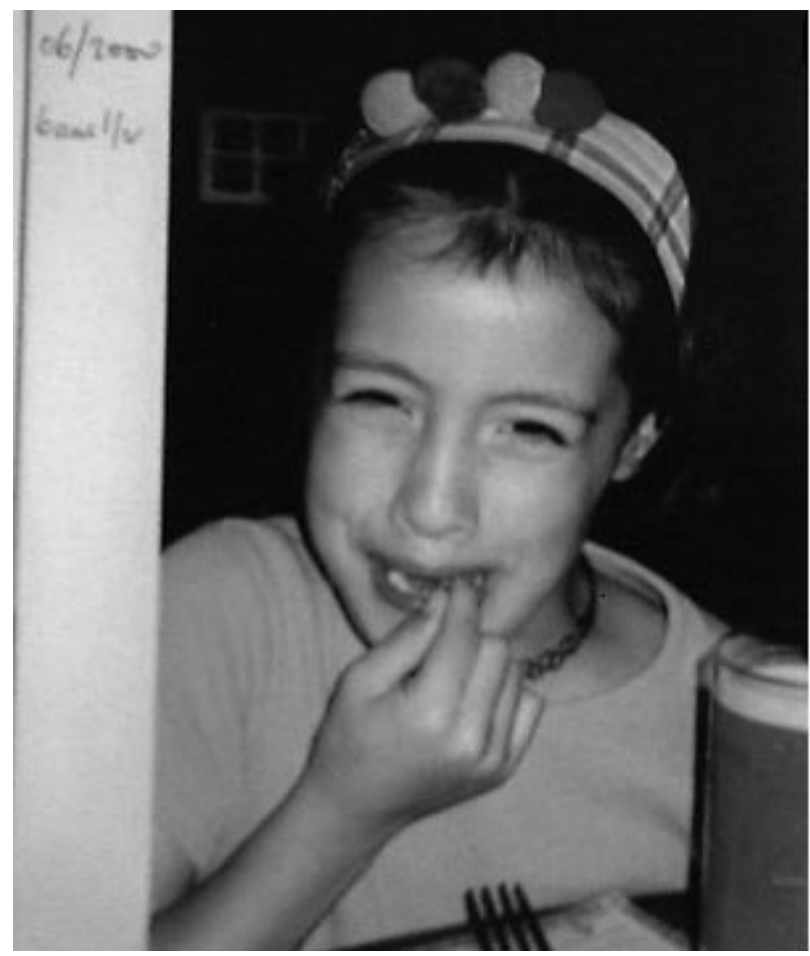

FIGURE 3A. Typical "crying" smiling face in a Ochoa syndrome. and lack of sphincter relaxation during voiding provoque detrusor hypertrophy, elevated voiding pressures and high pressure VUR, which represents a risk factor for the renal parenchyma. Post voiding residual urine increases risk of UTI. On imaging the bladder wall is trabeculated and thin with a limited functional capacity. These children generaly have diurnal and nocturnal urinary incontinence (22-25). Koff and all reported an associated VUR in half of 53 children, presenting with recurrent urinary tract infections, uninhibited bladder contractions on urodynamics and without associated neurological conditions (26). Mayo and Burns reported a significantly higher incidence of VUR $(50 \%)$ in 30 children, who had a dyssynergic voiding $173 \%$ had a symptomatic UTIs), compared to a second group of 97 children who had isolated bladder overactivity without dysynergia (they presented with urinary incontinence, $24 \%$ only had a VUR) and a third group of 64 children with diurnal urinary incontinence without urodynamic anomalies $(31 \%$ had urinary infections and only $8 \%$ of them had VUR) (27).

Several studies reported the cure of VUR by treatment of associated bladder instability with anticholinergics (28-31). Also, the amount of post surgical complications after uretero vesical reimplantation has been reported to be high in case of an associated uncontrolled bladder dysfunction $(32,33)$. Koff developed a theory that bladder instability induces VUR because of functional obstruction due to urethral sphincter contractions in response to uninhibited detrusor contractions; also a relationship exists between bladder sphincter dysfunction during bladder filling and

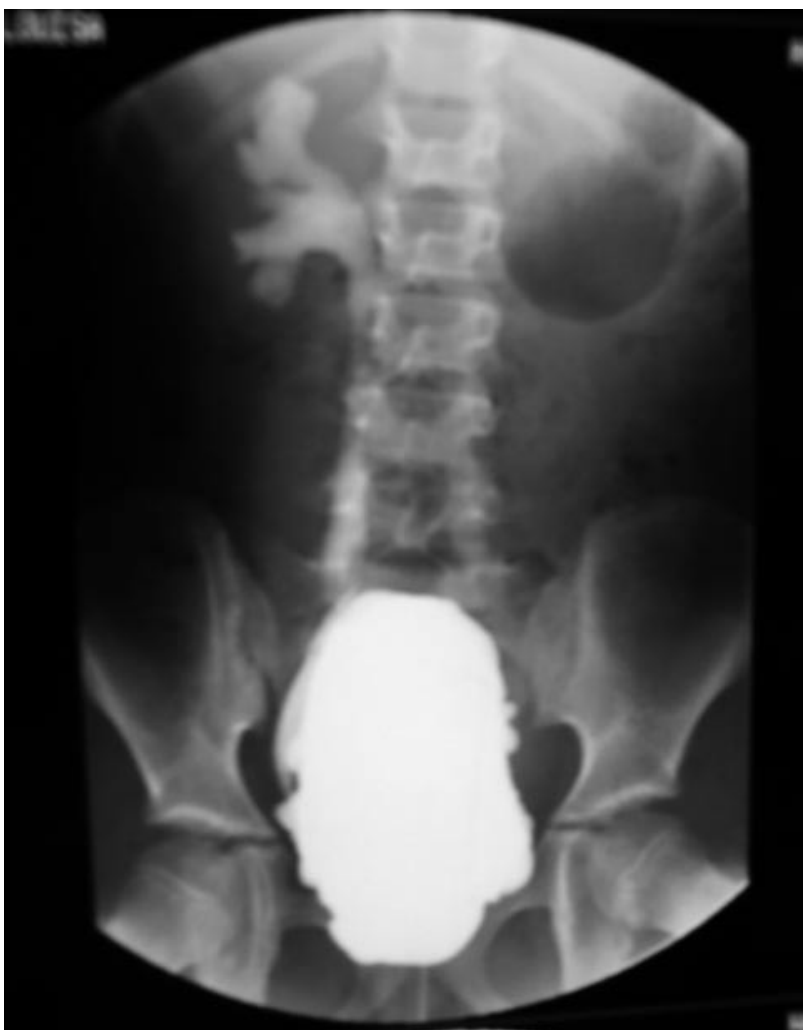

FIGURE 3B. Massive right side VUR in the same patient. 
VUR (34); identification and treatment of this dysfunction increases the probability of reflux resolution. In $1998 \mathrm{Koff}$ and all showed in a prospective study that from 143 children with primitive VUR, 66 had symptoms of elimination disorders: 18 children (27\%) had bladder instability; 15 $(23 \%)$ with an interrupted voiding and $33(50 \%)$ with constipation. Most of these children presented more than one of these disorders and all had received antibioprophylaxy. At least one of these elimination disorders was present in $77 \%$ of 70 children, who had recurrent urinary tract infection; only $16 \%$ of 73 children without urinary infections had one of the elimination disorders. 54 (82\%) from 66 children with elimination disorders have had vesico ureteral reimplantation because of recurrent urinary tract infections under antibioprophylaxy; only $12(18 \%)$ had spontaneous resolution of VUR. Also, only 16 (21\%) from 77 children without elimination disorders needed a vesico ureteral reimplantation because of recurrent infection; 61 (79\%) had spontaneous resolution of VUR. Between the three elimination disorders, the constipation is the one the most frequently observed in case of recurrent UTIs. Finally, most children, who had complications after vesico ureteral reimplantation, had an elimination disorder (35). So, the elimination disorders, associated with VUR increases the risk of infectious complications despite antibioprophylaxis, decreases the spontaneous resolution rate and increases the risk of complications after the surgery.

\section{Investigation of elimination disorders}

\section{- Investigation of urinary elimination disorders}

\section{Non invasive investigations:}

\section{Anamnesis and drinking/voiding chart:}

In children who have achieved voiding control, anamnesis clarifies voiding and drinking habits, persistence of eventual diurnal or nocturnal urine incontinence, notion of previous urinary tract infections, frequence of bowel movements; familial history, particularly regarding VUR, psychological problems, previous or/and undergoing

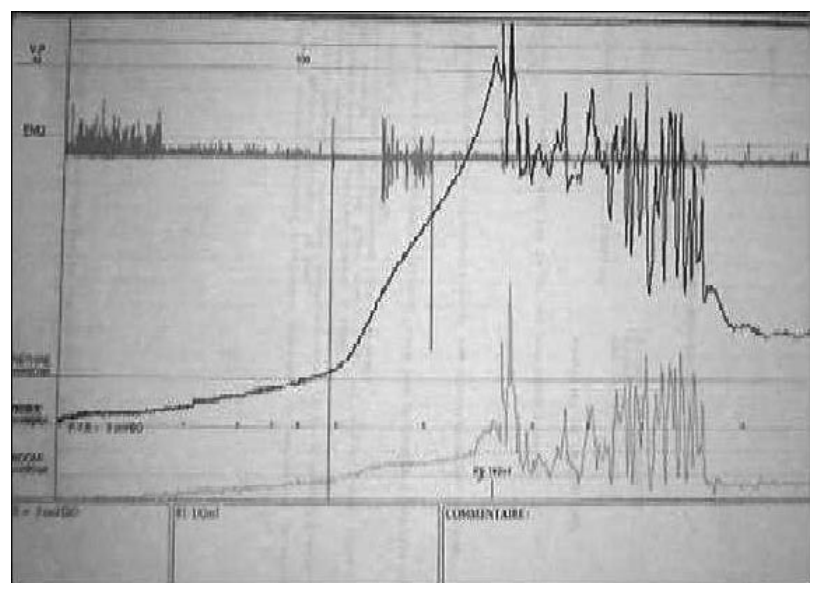

FIGURE 3C. Poorly compliant small bladder with dys synergia. treatments. Neuro-urological examination, including observation of voiding and urinary test; examination of the abdomen, perineum lombo sacral region, genital organs (including inspection of the uretral meatus), périnéal sensitivity, anal tonus, squeezing reflex, achylean reflexes, ability to walk on tiptoe and heels. The patient is asked to fill day by day a drinking and voiding chart with mention of fluid intake, when he voids and each time possible (usually at home) what amount of urine he has eliminated, incontinence episodes, stool passages, treatments... A drinking and voiding chart (DVC) is an essential non invasive tool: first, to collect information about the initial drinking and voiding habits of the child, then to follow the evolution of the condition all along the management

\section{Four hours observation test:}

In infants, when such symptoms as pollakiuria, urgency and incontinence are not easily identified, this test has a great importance: It consists in a four hours observation (generally by mother, assisted by a urotherapy nurse) of the frequence of micturations, their volume (by weighting the diapers) and residual urine, measured by ultrasound after every voiding. The data obtained are compared with norms for âge (36).

\section{Ultrasound:}

Ultrasound allows to visualize a dilatation of the upper urinary tract and eventual parenchymal lesions. It also allows to evaluate the bladder wall thickness. Immediately after voiding the volume of residual urine can be calculated. Being non invasive this investigation can be often repeated. The quantity of residual urine can also be measured by Bladderscan®.

\section{Simplified urodynamic study:}

Simplified urodynamic study consists of a uroflowmetry combined with a recording of perineum activity using surface electrodes. This investigation is especially indicated for the diagnosis of children with VUR associated with elimination disorders in a context of bladder-sphincter dyscoordination. It is also useful during biofeedback sessions (37).

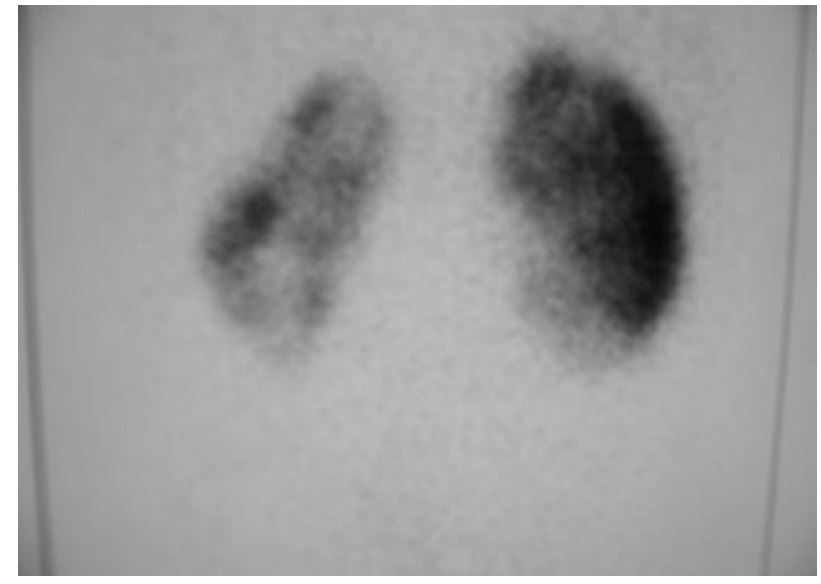

FIGURE 3D. Major right kidney parenchymal damage on the anterior view of a TC99 DMSA scan. 


\section{Invasive investigations:}

\section{Voiding cystourethrography:}

Necessary to the diagnostis of VUR, cystography also provides signs of elimination disorders: It allows to evaluate bladder capacity, bladder shape and residual urine, signs of constipation. During micturation, spinning top shape of the urethra in girls is a sign of dyssynergia (Figure $4 a-b)$; in boys functional or anatomical urethral obstacle (diaphragm, posterior urethral valve, stenosis) can also be identified. In boys, particularly if an urethral abnormality is suspected, a supra pubic voiding cystouretrogram is preferable to a retrograde access (38).

\section{Urodynamic studies:}

The complete urodynamic study consisting of uroflowmetry, profilometry, cystometry with or without sphincter activity recorded by surface electrodes, is rarely needed. Especially in newborns its interpretation is difficult. As this investigation requires a retrograde catheterism and

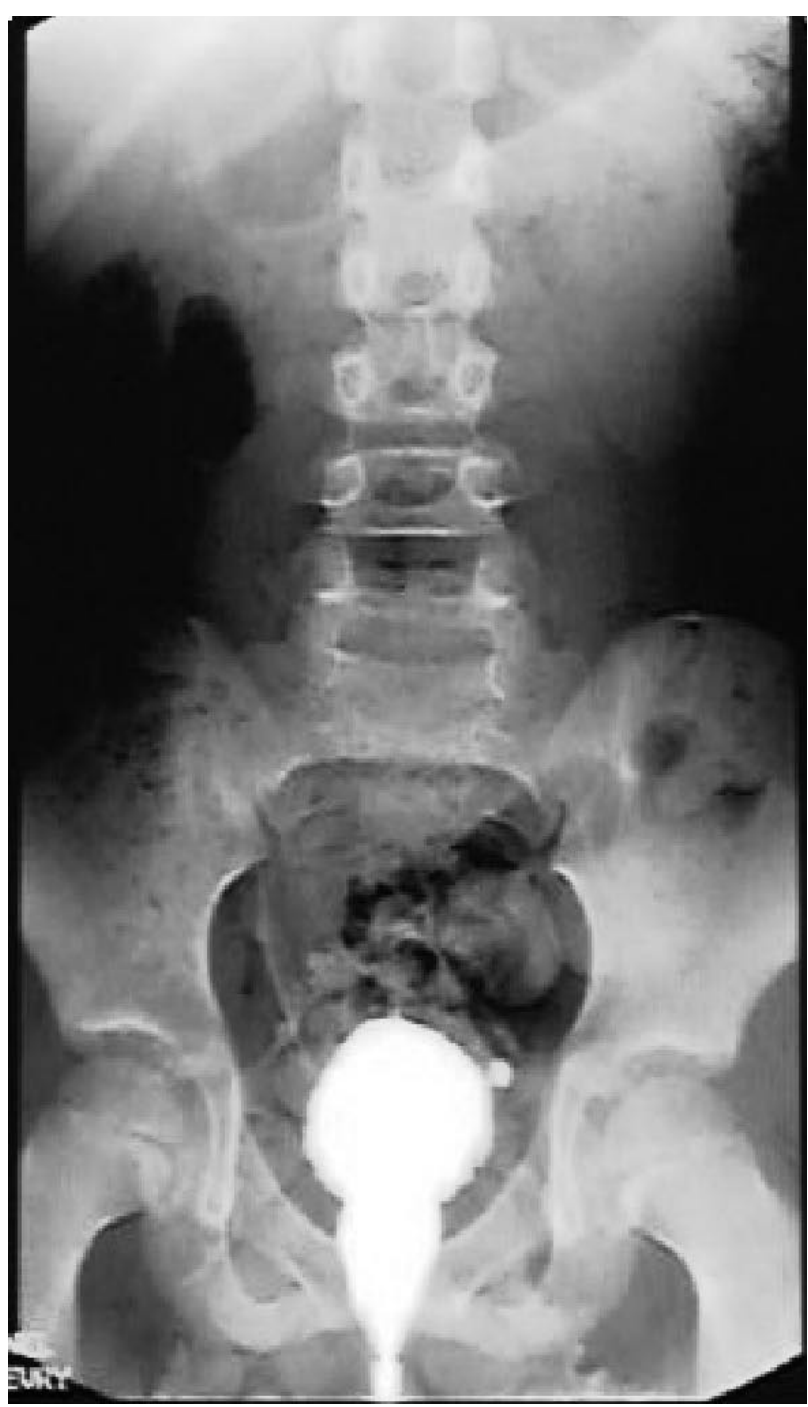

FIGURE 4A. Bladder sphincter dyscoordination with bowel fecal impaction and spinning top shape of the urethra. several bladder fillings, iatrogenic infectious complications may occur in the context of associated VUR and disorders of bladder emptying. A high grade VUR also can hide signs of low bladder compliance. A four hours observation study in infants or a simplified urodynamic study in older children are in most situations sufficient. Complete urodynamic study remains useful in severe elimination disorders, especially in neurogenic bladders valve bladders, as well as therapy resistant overactive bladders.

3. Video urodynamic study:

Cystourethrography and urodynamic study are combined; it allows to limit the number of invasive studies and provides simultaneous morphological and functional information.

\section{- Investigation of faecal elimination disorders}

\section{Non invasive investigations:}

\section{Anamnesis and calendar:}

Additionally to elements, mentioned above, it is necessary to clarify dietetary habits of the child, frequency of bowel movements and consistence of stool, presence of constipation or diarrhoea, undergoing or previous medication. Palpation of the abdomen appreciates the degree of constipation; Rectal examination, which is not systematic,

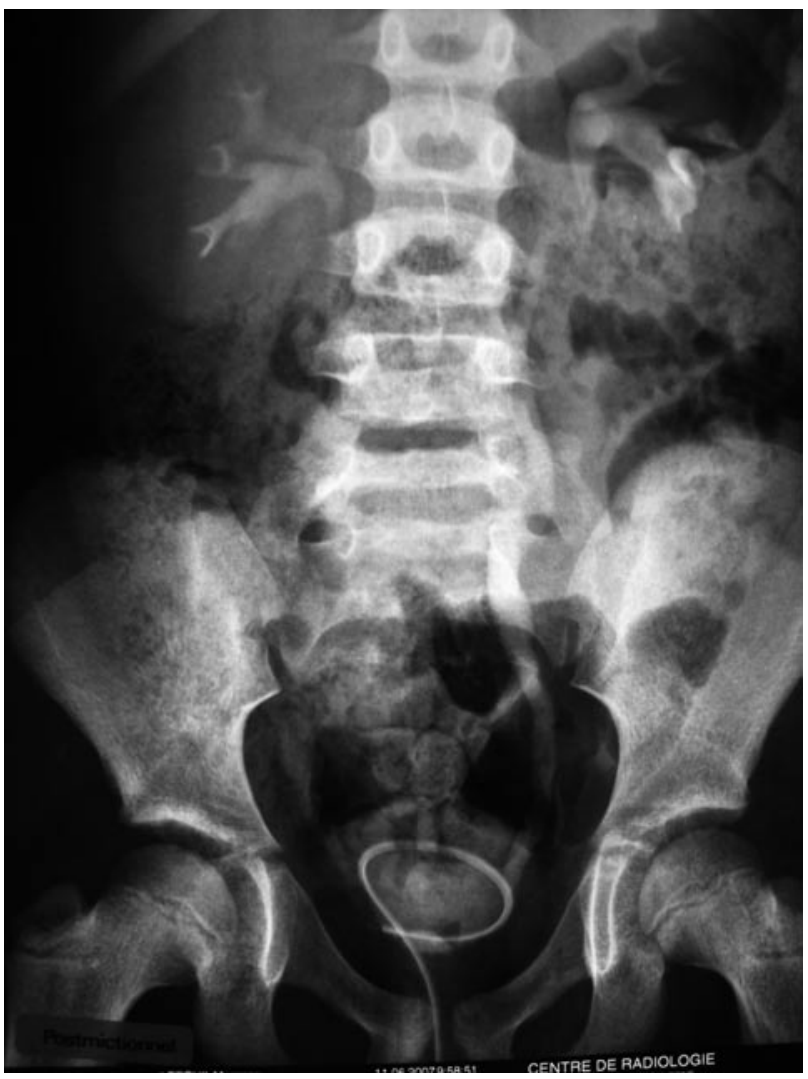

FIGURE 4B. Bilateral associated VUR. 
allows to evaluate the anal tonus and the existence of an eventual faecaloma.

\section{Plain abdomen X-Ray:}

Can be helpful for investigation of the degree of constipation, particularly in children with overweight, when abdominal palpation is not informative.

\section{Invasive investigations:}

Ano-rectal manometry and colonic opacification are rarely necessary.

\section{Treatment of urinary and intestinal elimination disorders}

Is based on the prevention of infections, the suppression of the post voiding residual urine and the treatment of an associated constipation. If surgical treatment of VUR is needed, it must be associated to the management of elimination disorders in the peri operative period. In many instances, an appropriate treatment of elimination disorders often leads to the VUR resolution.

\section{- Prevention of the infections}

\section{Antibio prophylaxis}

VUR and elimination disorders, represents a situation of high infectious risk for the upper urinary tract. Antibio prophylaxis is classically considered as an important factor in infection prevention; however permanent residual urine and faecal stasis often limit its efficacy and may lead to selection of resistant bacteria. The principle is to prescribe an antibiotic once daily, using one third or one fourth of the therapeutic dose for an acute infection dose. The most frequently used antibiotic is the association of trimetoprim-sulfometoxazol or trimetoprim alone. In fact, in the absence of placebo controlled study, the efficacy of antibio prophylaxis for the prevention of infectious complications in case of VUR and elimination disorders remains to be proven.

\section{Circumcision}

The prepucial mucosa is a reservoir of potentially pathogenic bacteria (such as proteus or pseudomonas aeruginosa); children, who have a severe uropathy could benefit of circumcision, especially when prophylaxis does not help to prevent UTI(s) and when vesico-ureteral reimplantation is not indicated or gives poor results (such as reimplantations in valve bladders or neuropathic bladders). (39-41).

In fact, the best way to prevent an urinary infection is the suppression of post voiding residual urine and the treatment of constipation.

\section{- Suppression of post voiding residual urine}

\section{Voiding training and biofeedback}

For all the children, who are able to control their micturations, the treatment of bladder emptying disorder associated with a VUR starts with the drinking-voiding charts and from drinking and voiding at regular intervals. In the case of an important residual urine, especially for children with a high grade VUR and with significant dilatation of the upper urinary tract, it could be useful to teach the child to void in several sequences. In these patients voiding in two or three times allows an optimization of bladder emptying and may contribute in some instances to avoid intermittent bladder catheterisations.

Non neuropathic disorders of the bladder-sphincter coordination are best managed with pelvic floor relaxation, which must to be taught by a specialized physiotherapist. Introduced in 1949 by Kegel, the technique of biofeedback is also used for children, who have urine and/or faecal elimination disorders because consecutive to a lack of perineum relaxation during voiding or defecation when conventional re-education techniques have failed (42). The activity of pelvic floor muscles is recorded with surface electrodes, which allows the child to visualise the muscles contractions. The aim of the visual or audio stimulation is to teach the child to relax as much as possible the perineum during the micturation. For children, to stimulate a good participation, video games can be adapted to the system The results reported of the use of this technique are excellent $(43,36)$. However approximately one-hour long training sessions are needed and they require a specialised urotherapist.

\section{Pharmacological treatment}

Are given either to improve the bladder contractility (cholinergic treatment type urecholine, in fact rarely prescribed nowadays), either to resolve a bladder neck functional obstruction (alphablockers), either to correct the detrusor overactivity (anti-cholinergic treatment, such as oxybutinin). Particularly in the context of an elimination disorder anticholinergics can provoke or worsen a pre existing constipation; Also oxybutinin can provoke all atropinic secondary effects. Tolterodine (Detrusitol®) is claimed to have similar positive effects as anticholinergics with a better tolerance, but this molecule is not approved for the paediatric usage and there are no controlled studies of its action in children (44). Favourable positive effects on the relaxation of the smooth muscle of the bladder neck and posterior urethra have been reported with Alphablokers particularly in children presenting post voiding residue after the surgical treatment of posterior urethral valves $(45,46)$. Still there are no controlled studies and the use of alpha blockers is theoretically restricted to adults.

\section{Clean intermittent catheterisation}

If the voiding re-education and pharmacological treatment are inefficient or impossible (in small children or in case of neuropathic bladders), for the resolution of residual urine, particularly if the upper urinary tract is threatened, more aggressive treatments, like clean intermittent catheterisation $(\mathrm{CIC})$, is indicated. This technique, introduced in the beginning of the seventies by Lapidès (47), clearly proved its efficacy in prevention of febrile infections and renal parenchyma scars (48-51). Clean intermittent catheterisation permits the resolution of VUR in 30 to $80 \%$ of cases in neuropathic bladders (52-54). This technique was also proposed as an alternative to cutaneous vesicostomy for the treatment of massive VUR with a significant residual urine in infants and in the posterior urethral valves (7). The catheterisation is made either by the child himself, if he is sufficiently autonomous (usually from eight years old), either by 
a caregiver or by the parents. Four to six catheterisations daily are usually necessary. If the urethra is too sensitive or difficult to catheterize (particularly in boys, treated posterior urethral valves), it can be necessary to create a continent catheterisable stoma as described by Mitrofanoff (55).

\section{Other invasive methods of evacuation of residual post voi- ding urine associated with VUR}

Exceptionally, when all other therapeutic options are inefficient or could not be realised (deep cerebral palsy, severe psychiatric disorders), and when exists a real danger for the upper urinary tract, an incontinent urine derivation can be considered (temporary type vesicostomy (56-58), or $Y$ Sober type cutaneous ureterostomy, and even more exceptionally an ileal conduit or an endoscopic sphincterotomy.

\section{- The treatment of constipation}

In the patients, who have constipation, associated with a VUR and urinary elimination disorders, it is essential to achiev a regular and complete intestinal emptying with the help of appropriate diet, rich in fibers, limiting chocolates etc; medications facilitating the intestinal transit of feces; suppositories or retrograde enemas stimulating the exonerations. In extreme cases (especially in the neurological disorders and in the anorectal malformations) a continent appendico coecostomy as described by Malone is created to allow antegrade enemas (59).

\section{- Surgical treatment of VUR}

In case of a high grade primary VUR generating significant post voiding residue, an ureteral re implantation can be indicated. In all other cases, the treatment of eliminations disorders is the priority and indications for surgical VUR treatment are limited. Surgery should not be considered without a péri operative appropriate treatment of elimination disorders and bladder-sphincter dysfunction.

\section{REFERENCES AND RECOMENDED READINGS (*of special interest, ${ }^{* *}$ of outstanding interest)}

1. BURBRIGE, K.A.; LEBOWITZ, R.L.; COLODNY, A.H. y cols.: "The megacystis-megaureter syndrome". J. Urol., 131: 1133, 1984.

2. MANDELL, J.; LEBOVITZ, R.L.; PETERS, C.A. y cols.: "Prenatal diagnosis of the megacystis-megaureter association". J. Urol., 148: 1487, 1992.

3. ANDERSON, P.A.M.; RICKWOOD, A.M.K.: "Features of primary vesico-ureteric reflux detected by prenatal sonography". Br. J. Urol., 67: 267, 1991.

4. YEUNG, C.K.; GODLEY, M.L.; DHILLON, H.K. y cols.: "The characteristics of primary vesico-ureteric reflux in male and female infants with prenatal hydronephrosis". Br. J. Urol., 80: 319, 1997.

5. RING, E.; PETRISCH, P.; RICCABONA, M. y cols.: "Primary vesicoureteral reflux in infants with a dilated fetal urinary tract”. Eur. J. Pediatr., 152: 523, 1993.
6. SILLEN, U.; BACHELARD, M.; HANSSON, S. y cols.: "Videocystometric recording of dilating reflux in infancy". J. Urol., 155: 1711, 1996.

7. SILLEN, U.: "Vesicoureteral reflux in infants". Pediatr. Nephrol., 13: 355, 1999.

8. GRIFFITS, D.J.; SCHOLTMEIJER, R.J.: "Vesicoureteral reflux and lower urinary tract dysfunction: Evidence for 2 different reflux/dysfunction complexes". J. Urol., 137: 240, 1987.

9. LOTTMANN, H.; MELIN, Y.; CENDRON, J.: "Valves de l'urètre posterieur". Chir. Pediatr., 27: 15, 1986.

10. PARKHOUSE, H.F.; BARRAT, T.M.; DILLON, M.J. y cols.: "Long-term outcome of boys with posterior urethral valves". Br. J. Urol., 62: 59, 1988.

11. PARKHOUSE, H.F.; WOODHOUSE, C.R.: "Longterm status of patients with posterior urethral valves". Urol. Clin. N. Amer., 17: 373,1990.

12. PETERS, C.A.; BOLKIER, M.; BAUER, S.B. y cols.: "The urodynamic consequences of posterior urethral valves". J. Urol., 144: 122, 1990.

13. PETERS, C.A.; VASAVADA, S.; DATOR, D. y cols.: "The effect of obstruction on developing bladder". J. Urol., 148: 491, 1992.

14. HOLMDAHL, G.; SILLEN, U.; HANSON, E. y cols.: "Bladder dysfunction in boys with posterior urethral valve before and after puberty". J. Urol., 155: 694, 1996.

15. Mc GUIRE, E.J.; WOODSIDE, J.R.; BORDON, T.A. y cols.: "Prognostic value of urodynamic testing in myelodysplastic patients". J. Urol., 126: 205, 1981.

16. COHEN, R.A.; RUSHTON, H.G.; BELMAN, A.B. y cols.: "Renal scarring and vesico-ureteral reflux in children with myelodysplasia”. J. Urol., pp.144-8, 1990.

17. LOTTMANN, H.; ROUSSEAU, G.; ROUFFET, M.J. y cols.: "Pathologie de la jonction urétéro-vésicale dans les vessies neurologiques de l'enfant et de l'adolescent. Etude rétrospective de 119 patients". Ann. Urol., 4: 203, 1998

18. HINMAN, F. Jr.; BAUMANN, F.W.: "Vesical and ureteral damage from voiding dysfunction in boys without neurologique or obstructive disease". J. Urol., 109: 727, 1973.

19. RUSHTON, H.G.: "Wetting and functional disorders". Urol. Clin. North Am., 75: 75, 1995.

20. OCHOA, B.: "Can a congenital dysfunctional bladder be diagnosed from a smile? The Ochoa syndrome updated". Pediatr. Nephrol., 19: 6, 2004.

21. HINMAN, F. Jr.: "Non-neurogenic neurogenic bladder (the Hinman syndrome) - 15 years later". J. Urol., 136: 769, 1986.

22. HOMSY, Y.: "Dysfunctional voiding syndromes and vesicoureteral reflux". Pediatr. Nephrol., 8: 116, 1994.

23. PEREZ, L.M.; RUSHTON, H.G.: "A pragmatic approach to the evaluation and management of non-neuropathic daytime voiding disorders". Gearhart J, Rink R, Mouriquand P. eds, Pediatric Urology, Philadelphia. Saunders, 30: 470, 2001.

24. AUBERT, D.: "Instabilité vésicale et reflux: Une association pathogène fréquente". Chir. Pédiatr., 25: 114, 1984.

25. AVEROUS, M.; BISERTE, J.; DORÉ, B.: "Physiopathologie du reflux vésico-rénal”. Prog. Urol., 8: 685, 1998. 
26. KOFF, S.A.; LAPIDES, J.; PIAZZA, D.H.: “Association of urinary tract infection and reflux with uninhibited bladder contractions and voluntary sphincteric obstruction". J. Urol., 122: 373, 1979.

27. MAYO, M.E.; BURNS, M.W.: "Urodynamic studies in children who wet". Br. J. Urol., 65: 641, 1990.

28. HOMSY, Y.L.; NSOULI, J.; HAMBERGER, B. y cols.: "Effects of oxybutinin on vesico-ureteral reflux in children". J. Urol., 134: 1168, 1985.

29. SERUCA, H.: "Vesicoureteral reflux and voiding dysfunction: Prospective study". J. Urol., 142: 494, 1989.

30. KOFF, S.A.; MURTAGH, D.S.: "The uninhibited bladder in children, effects of treatment on recurrence of urinary infection and on vesicoureteral resolution". J. Urol., 130: 1138, 1983.

31. AVEROUS, M.: "Le syndrome d'immaturité vésicale. A propos de 1097 observations". J. Urol. Paris, 91 : 257, 1985.

32. HINMAN, F.Jr.; BAUMAN, F.W.: "Complications of vesicoureteral operations from incoordination of micturation". J. Urol., 116: 638, 1976.

33. NOE, H.N.: "The role of dysfunctional voiding in failure or complication of ureteral reimplantation for primary reflux". J. Urol., 134: 1172, 1985.

34. KOFF, S.A.: "Relationship between dysfunctional voiding and reflux". J. Urol., 148: 1703, 1992.

35. KOFF, S.A.; WAGNER, T.T.; JAYANTHI, V.R.: "The relationship among dysfunctional elimination syndromes primary vesicoureteral reflux and urinary tract infections in children". J. Urol., 160: 1019, 1998.

36. HOLMDAHL, G.; HANSON, E.; HANSON, M. y cols.: "Four-hour voiding observation in healthy infants". J. Urol., 156: 1809, 1996.

37. PFISTER, C.; DACHER, J.N.; GAUCHER, S. y cols.: "The usefulness of a minimal urodynamique evaluation and pelvic floor biofeedback in children with chronic voiding dysfunction". BJU Int., 84: 1054,1999.

38. ROUX-DESSARPS, S.; LOTTMANN, H.; MARICHEZ, M. y cols.: "Bilan étiologique des troubles mictionnels complexes (TMC) du garçon : Evaluation de la stratégie d'imagerie à partir d'une étude rétrospective de 58 dossiers". Ann. Urol., 32: 217, 1998.

39. WISWELL, T.E.: "Prepuce presence portends prevalence of potentially perilous periurethral pathogens". J. Urol., 148: 739, 1992.

40. SCHOEN, E.J.; ANDERSON, G.; BOHON, C. y cols.: "Report of task force on circumcision". Pediatrics, 84: 388, 1989.

41. RUSHTON, H.G.; MAJD, M.: "Pyelonephritis in male infants: How important is the foreskin?”. J. Urol., 148: 733, 1992.

42. KEGEL, A.H.: "The physiologic treatment of poor tone and function of the genital muscles and of urinary stress incontinence". World J. Surg. Obstet. Gynecol., 57: 527, 1949.

43. McKENNA, P.H.; HERNDON, C.D.A.; CONNERY, S. y cols.: "Pelvic floor muscle retraining for pediatric voiding dysfunction using interactive computer games". J. Urol., 162: 1056, 1999.
44. HJÄLMÄS, K.; HELLSTRÖM, A.L.; MOGREN, K. y cols.: "The overactive bladder in children: A potential future indication for tolterodine". BJU International, 87: 569, 2001

45. AUSTIN, P.F.; HOMSY, Y.L.; MASEL, J.L. y cols.: "Alpha-adrenergic blockade in children with neuropathic and nonneuropathic voiding dysfunction". J. Urol., 162: 1064, 1999.

46. BOUCHOT, O.; BUZELIN, J.M.; LABAT, J.J.: "Longterm efficacy of anticholinergic and alpha-blockader drugs on the detrusor muscle in children with myelomeningocele". J. Urol. Paris, 94: 83, 1988.

47. LAPIDES, J.; DIOKNO, A.C.; SILBER, S.J. y cols.: "Clean intermittent self-catheterization in the treatment of urinary tract disease". J. Urol., 107: 458, 1972.

48. BROCK, W.A.; SO, E.P.; HARBACH, L.B. y cols.: "Intermittent catheterisation in the management of neurogenic vesical dysfunction in children". J. Urol., 125: 391, 1981.

49. CASS, A.S.; LUXEMBERG, M.; JOHSON, C.F. y cols.: "Management of neurogenic bladder in 413 children". J. Urol., 132: 521, 1984.

50. GERANIOTIS, E.; KOFF, S.A.; ENRILE, B.: "The prophylactic use of clean intermittent catheterisation in the treatment of infants and young children with myelomeningocele and neurogenic bladder dysfunction". J. Urol., 139: 85, 1988.

51. KASABIAN, N.G.; VLACHIOTIS, J.D.; LAIS, A. y cols.: "The prophylactic value of clean intermittent catheterisation and anticholinergic medication in newborns and infants with myelodysplasia at risk of developing urinary tract deterioration". Am. J. Dis. Child., 151: 944, 1994

52. KASS, E.J.; KOFF, S.A.; DIOKNO, A.C.: "Fate of vesicoureteral reflux in children with neuropathic bladder". J. Urol., 125: 63, 1981.

53. MERLINI, E.; BESEGHI, U.; DE CASTRO, R. y cols.: "Treatment of vesicoureteric reflux in the neurogenic bladder”. Br. J. Urol., 72: 969, 1993.

54. PEREZ-MARREDO, R.; DIMMOK, W.; CHURCHILL, B.M. y cols.: "Clean intermittent catheterisation in myelomeningocele children less than 3 years". J. Urol., 128: 779, 1982.

55. MITROFANOFF, P.: "Cystostomie continente transappendiculaire dans le traitement des vessies neurologiques". Chir. Pediatr., 21: 197, 1980.

56. STEELE, B.T.; ROBITAILLE, P.; DE MARIA, J. y cols.: "Follow up of prenatally recognized vesicoureteric reflux". J. Pediatr., 115: 95, 1989.

57. GORDON, A.C.; THOMAS, D.F.M.; ARTHUR, R.J. y cols.: "Prenatally diagnosed reflux: A follow up study". Br. J. Urol., 65: 407, 1991.

58. ANDERSON, P.A.M.; RICKWOOD, A.M.K.: "Features of primary vesicoureteric reflux detected by prenatal sonography". Br. J. Urol., 67: 267, 1991.

59. MALONE, P.S.; RANSLEY, P.G.; KIELY, E.M.: "Preliminary report: The antegrade continence enema". Lancet, 336: 1217, 1990. 